\title{
Clinical and epidemiological characteristics and morphological peculiarities of urogenital trichomoniasis nowadays
}

\author{
H. I. Mavrov(1)*1,2,A-F , T. V. Osinska ${ }^{1, A-D}$, P. V. Fedorych ${ }^{3, A-D}$
}

${ }^{1} \mathrm{SI}$ “Institute of Dermatology and Venereology of National Academy of Medical Sciences of Ukraine”, Kharkiv, ${ }^{2}$ Kharkiv Medical Academy of Postgraduate Education, Ukraine, ${ }^{3}$ Ukrainian Military Medical Academy, Kyiv, Ukraine

A - research concept and design; B - collection and/or assembly of data; C - data analysis and interpretation; D - writing the article; $\mathrm{E}$ - critical revision of the article; $\mathrm{F}$ - final approval of the article

Key words:

Trichomonas

vaginalis,

Trichomonas tenax,

Pentatrichomonas

hominis,

co-infections,

ultrastructure.

Pathologia

2020; 17 (1), 52-59

*E-mail:

uniidiv@gmail.com

Importance of the topic is stipulated with the current significant spread of infectious diseases of the urogenital tract, caused by the representatives of the protozoa genus Trichomonas.

Aim. Evaluate the prevalence and peculiarities of contemporary trichomonas infection (Trichomonas vaginalis, Pentatrichomonas hominis, Trichomonas tenax), with the consideration of the associated bacterial infections that cause the urogenital pathology and the ultrastructural peculiarities of Trichomonas vaginalis morphotypes in the patients with chronic infectious diseases of the genitourinary organs.

Material and methods. The research was carried out among 377 patients with chronic infectious diseases of the genitourinary organs. Routine bacterioscopic and bacteriological methods were applied. In addition, Trichomonas tenax and Pentatrichomonas hominis were detected using real-time polymerase chain reaction and applying original experimental primers. The ultrastructure of the trichomonads was studied using a PEM-125K electron microscope equipped with the SAI-01A (SELMI) system, using a CCD camera DX 2 and KAPPA software package.

Results. Trichomonas vaginalis was detected in $48.3 \%$ using the methods of optical microscopy and culture media inoculation. Trichomonas tenax was detected in $18.2 \%$ and Pentatrichomonas hominis was detected in $67.1 \%$ with the polymerase chain reaction. Development of the pathological process in the urogenital system of the studied patients (up to $90 \%$ ) was caused with the microbial associations, in particular, with Ureaplasma urealyticum $(26.1 \%)$, Chlamydia trachomatis (16.7 \%), Mycoplasma hominis and Mycoplasma genitalium (13.9\%) and various kinds of opportunistic pathogenic microflora (up to $60 \%$ ), which lead to dysbiosis of urogenital system. It was proved that the oval morphotype Trichomonas vaginalis may be referred to the virulent forms; it was detected more often (68\%) than the piriform morphotype.

Conclusions. Possible presence of trichomonads of three species: Trichomonas vaginalis, Trichomonas tenax, Pentatrichomonas hominis, in particular in pathological microbial associations, as important factors of the emergence and / or development of the pathological process, was established in the human genitourinary system. It is reasonable to refer the oval morphotype Trichomonas vaginalis to the virulent forms of this agent.

Киючові слова: Trichomonas vaginalis, Trichomonas tenax, Pentatrichomonas hominis, асоційовані інфекції, ультраструктура.

Патологія. 2020.

T. 17, № 1(48).

C. $52-59$

\section{Клініко-епідеміологічні характеристики і морфологічні особливості сучасного сечостатевого трихомонозу}

\section{Г. І. Мавров, Т. В. Осінська, П. В. Федорич}

Актуальність теми зумовлена значним поширенням інфеекційних захворювань сечостатевих шляхів, що викликані представниками роду найпростіших Trichomonas.

Мета роботи - оцінити поширеність та особливості сучасної трихомонадної інвазії (Trichomonas vaginalis, Pentatrichomonas hominis, Trichomonas tenax), враховуючи асоційовані бактеріальні інфекції, що зумовлюють патологію урогенітального тракту, та ультраструктурні особливості морфотипів Trichomonas vaginalis у хворих на хронічні інфекційні захворювання сечостатевих органів.

Матеріали та методи. Дослідження виконали у 377 пацієнтів із хронічними інфекційними захворюваннями сечостатевих органів. Використовували рутинні бактеріоскопічний і бактеріологічний методи. Крім того, за допомогою методу полімеразної ланцюгової реакції в реальному часі, використовуючи авторські експериментальні оригінальні праймери, виявляли Trichomonas tenax i Pentatrichomonas hominis. Ультраструктуру трихомонад вивчали за допомогою електронного мікроскопа ПЕМ-125К, забезпеченого системою САИ-01A (SELMI), з використанням CCD камери DX 2 і пакету програм KAPPA.

Результати. За допомогою методів оптичної мікроскопії та засівів на поживне середовище Trichomonas vaginalis виявили у 48,3 \% хворих. Методом полімеразної ланцюгової реакції Trichomonas tenax визначили у 18,2 \%, Pentatrichomonas hominis-y 67,1 \%. Розвиток патологічного процесу в сечостатевій системі обстежених (до 90 \%) зумовлений мікробними асоціаціями, а саме 3 Ureaplasma urealyticum (26,1 \%), Chlamydia trachomatis (16,7\%), Mycoplasma hominis i Mycoplasma genitalium (13,9\%) та різних видів умовно-патогенної мікрофрлори (до 60 \%), що спричиняють дисбіоз сечостатевої системи. Показано, що овальний морфотип Trichomonas vaginalis можна класифікувати як вірулентну форму, його виявляли частіше (68 \%), ніж грушоподібний.

Висновки. Встановили можливість наявності у сечостатевій системі людини, зокрема в патологічних мікробних асоціаціях, трихомонад 3 видів: Trichomonas vaginalis, Trichomonas tenax, Pentatrichomonas hominis - як важливих чинників виникнення та/або розвитку патологічного процесу. Овальний морфотип Trichomonas vaginalis доцільно вважати вірулентною формою цього збудника. 


\section{Клинико-эпидемиологические характеристики и морфологические особенности современного мочеполового трихомоноза}

\section{Г. И. Мавров, Т. В. Осинская, П. В. Федорич}

Актуальность темы обусловлена широким распространением воспалительных заболеваний мочеполовых путей, которые вызваны представителями рода простейших Trichomonas.

Цель работы - оценить распространенность и особенности современной трихомонадной инвазии (Trichomonas vaginalis, Pentatrichomonas hominis, Trichomonas tenax), учитывая ассоциированные бактериальные инфекции, обусловливающие патологию урогенитального тракта, и ультраструктурные особенности морфотипов Trichomonas vaginalis y больных, страдающих хроническими воспалительными заболеваниями мочеполовых органов.

Материалы и методы. Исследования проведены у 377 пациентов с хроническими воспалительными заболеваниями мочеполовых органов. Использовали рутинные бактериоскопический и бактериологический методы. Кроме того, с помощью метода полимеразной цепной реакции в реальном времени, используя авторские экспериментальные оригинальные праймеры, определяли Trichomonas tenax и Pentatrichomonas hominis. Ультраструктуру трихомонад изучили с помощью электронного микроскопа ПЭМ-125К, обеспеченного системой САИ-01A (SELMI), с использованием CCD камеры DX 2 и пакета программ KAPPA.

Результаты. С помощью методов оптической микроскопии и посевов на питательную среду Trichomonas vaginalis обнаружили у 48,3 $\pm 3,5$ \% больных. Методом полимеразной цепной реакции Trichomonas tenax определили у 18,2 $\pm 2,9 \%$, Pentatrichomonas hominis - y $67,1 \pm 3,5 \%$. Развитие патологического процесса в мочеполовой системе обследованных (до 90 \%) обусловлено микробными ассоциациями, а именно с Ureaplasma urealyticum (26,1%), Chlamydia trachomatis (16,7 \%), Mycoplasma hominis и Mycoplasma genitalium (13,9\%) и различных видов условно-патогенной микрофрлоры (до 60 \%), которые вызывают дисбиоз мочеполовой системы. Показано, что овальный морфотип Trichomonas vaginalis можно классифицировать как вирулентную форму, его обнаруживали чаще (68 \%), чем грушевидный.

Выводы. Установлена возможность наличия в мочеполовой системе человека, в том числе в патологических микробных ассоциациях, трихомонад 3 видов: Trichomonas vaginalis, Trichomonas tenax, Pentatrichomonas hominis - как важных факторов возникновения и/или развития патологического процесса. Овальный морфотип Trichomonas vaginalis целесообразно считать вирулентной формой этого возбудителя.

At the present stage, sexually transmitted infections (STIs) constitute an urgent global problem of healthcare. Today, trichomoniasis (ICD-10 code A59) continues to occupy an undisputed leading position among the sexually transmitted infections in terms of the number of cases. According to $\mathrm{WHO}$, the annual global incidence of urogenital trichomoniasis (UT) is about 270 million people. In Ukraine, about 250000 patients per year are officially reported on average, of which $40 \%$ are women and $30 \%$ are men of fertile age, which raises particular concern [1-3].

Contemporary trichomonas infection is characterized with mixed chronic recurrent oligosymptomatic course, multiple lesions of the genitourinary system; it has a negative impact on fertility of the patients, increases the risk of adverse gestational complications and perinatal infection of children; it is characterized with complexity of diagnostics and high torpidity to the administered therapy [4-7].

Nowadays it is proved that the trichomonas infection contributes to the development of extragenital pathology, secondary immune deficiency, increases the risk of hyperplastic processes in the urogenital tract of patients and affects their psycho-emotional state [8-12].

At the present stage, trichomoniasis is considered a mixed protozoan-bacterial-viral infection. In particular, it was proved that $T$. vaginalis plays a role in formation of pathogenic microbiocenoses that can cause imbalance of the urinary microbiota in both women and men. Today, special attention should be paid to the ability of trichomonads to capture and reserve various pathogenic microorganisms because of their incomplete phagocytosis - 'reservoir' or so-called TANK function. This stipulates the possibility of prolonged persistence of bacteria, fungi and viruses, in particular the HIV agent within the tricho- monas, and explains the unsuccessful attempts to diagnose and eliminate the relevant microorganisms. In addition, it was reported that pathogenic microflora could block nitro groups in imidazole compounds, thus impeding the treatment of urogenital trichomoniasis [1,6,12-14].

Another feature of contemporary trichomoniasis is the ability of Trichomonas vaginalis to generate so-called atypical forms. Therefore, they greatly vary in terms of their shape, size, presence of flagella and nuclei, which challenges the diagnostics and causes some difficulties in the disease therapy, especially chronic recurrent forms [3,12].

For a long time, only Trichomonas vaginalis was considered to be capable of living in the human urogenital tract. Today, the possibility of prolonged colonization and pathology of the human genitourinary system caused by both Trichomonas vaginalis and Trichomonas non vaginalis (Pentatrichomonas hominis and Trichomonas tenax) is proved $[14,15]$.

Therefore, considering the above aspects of contemporary trichomonal infection of the genitourinary system, we consider it relevant to conduct the research in order to determine the clinical, epidemiological and morphological characteristics of the urogenital trichomoniasis, which will allow optimizing the diagnostic and preventive measures aimed to avoid complications of this disease.

\section{Aim}

Evaluate the prevalence and peculiarities of contemporary trichomonal infection (Trichomonas vaginalis, Pentatrichomonas hominis, Trichomonas tenax), with the consideration of the associated bacterial infections
Ключевые слова: Trichomonas vaginalis, Trichomonas tenax, Pentatrichomonas hominis, ассоциированные инфекции, ультраструктура.

Патология. 2020. T. 17, № 1(48).

C. $52-59$ 
that cause the urogenital pathology and the ultrastructural peculiarities of Trichomonas vaginalis morphotypes in the patients with chronic infectious diseases of the genitourinary organs.

\section{Materials and methods}

Patients were enrolled to the study at the State Institution "Institute of Dermatology and Venereology of the National Academy of Medical Sciences of Ukraine" during 2018-2019.

Laboratory diagnostics of Trichomonas vaginals and related infections - light microscopy, cultural research, polymerase chain reaction - were performed at the State Institution "Institute of Dermatology and Venereology of the National Academy of Medical Sciences of Ukraine" (Kharkiv) and Kyiv City Oleksandrivska Clinical Hospital clinical base of the Ukrainian Military Medical Academy (Kyiv). Electron microscopic examination was performed at the State Institution "Institute of Cryobiology and Cryomedicine of the National Academy of Sciences of Ukraine" (Kharkiv) - by agreement.

Original sampling of the examined patients consisted of 377 persons that were screened for STIs, with the consideration of their age (from 17 to 80 , mean age $33.2 \pm 2.5$ years) and sex (females -145 , males -131 ). Screening with bacteriological, bacterioscopic methods and real-time polymerase chain reaction (real-time PCR) identified the groups of patients, that are mentioned in this research. Further detailed examination was carried out in 247 patients (65.5\% of the original sampling), in particular: Trichomonas vaginalis was verified with bacteriological and bacterioscopic methods in $48.3 \%$ cases, in particular in 97 of 201 patients (females - 38, males - 59); verification with real-time PCR method using the authors' experimental original primers confirmed: Trichomonas tenax in 32 of 176 (18.2\%) cases (males 19 , females - 13) and Pentatrichomonas hominis in 118 of $176(67.1 \%)$ cases (males -69 , females -59$)$. The age range of the examined patients was wide enough; for instance, the age of male patients varied from 18 to 80 years (mean age was 36.8 years), and female - from 17 to 74 years (mean -35.2 years). The peak incidence was $27-34$ years $(64.6 \%)$.

The control group did not differ significantly in age and sex characteristics from the study groups, which made it possible to compare them correctly with other parameters.

Criteria for enrollment to the study: presence of chronic infectious diseases of the genitourinary tract, in particular, with trichomonas etiology and slow course, poor symptoms and disease duration over 1 year, voluntary informed consent. Exclusion criteria: patient refusal, administration of anti-protist and antimicrobial therapy over the last month before the study.

Diagnostics of trichomonas infection was based on the results of a comprehensive examination, which included: detection of trichomonads in smear sampled from urethra in males, vagina and cervical canal in females, and cultural study of biological material in liquid nutrient medium based on M 305 broth (HiMedia, India) with further agent detection by microscopy of native wet preparations. For microscopic imaging of protozoa in smear, the material was fixed and then stained according to Gram's technique $[3,6,7]$.

The real-time PCR used the DT-96 amplifier, "Femoflor-16" reagent set (R\&D company "DNA Technology", the Russian Federation) and primers to detect different types of trichomonads, including the authors' original primers for detection of Trichomonas tenax and Pentatrichomonas hominis [15]. "Femoflor-16" reagent set is designated for quantitative determination of microflora associated with bacterial vaginosis (BV) in female biological fluids. The application method for "Femoflor-16" was adapted by us to determine the appropriate microflora in men. "Femoflor-16" reagent set allows to quantify the following parameters: total bacterial mass, Lactobacillus spp., Enterobacteriaceae, Streptococcus spp., Staphylococcus spp., Gardnerella vaginalis/Prevotella bivia/Porphyromonas spp., Eubacterium spp., Sneathia spp./Leptotrihia spp./Fusobacterium spp., Megasphaera spp./Neilonella spp./Dialister spp., Lachnobacterium spp./ Clostridium spp., Mobiluncus spp./Corynebacterium spp., Peptostreptococcus spp., Atopobium vaginae, Candida spp., Mycoplasma hominis, Ureaplasma (urealyticum + parvum), Mycoplasma genitalium [2].

Electron microscopic object of study was the trichomonad cultures of day 5-9, which were isolated from 55 patients. The material was pre-mixed with the equal volume of $3 \%$ glutaraldehyde prepared on phosphate buffer $(\mathrm{pH}$ 7.3 to 7.4 ). Fixation time -4 hours. The cell suspension was centrifuged at $750 \mathrm{rpm}$. The precipitate was washed in phosphate buffer and postfixed in $1 \%$ solution of osmium tetroxide for 2 hours. After dehydration with ethyl alcohol of increasing concentration (from $30 \%$ to $96 \%$, twice in absolute alcohol) and propylene oxide, the samples were impregnated with a mixture of Epon-araldite-propylene oxide, then they were put in Epon-araldite and polymerized at $60{ }^{\circ} \mathrm{C}$ for 48 hours. To select the desired area of the study, semithin sections with thickness of $0.5 \mu \mathrm{m}$ were made, which were stained with methylene blue and studied with LUMAM-MP-4 microscope. For electron microscopy, ultrathin sections obtained with UMTP-7 ultramicrotome were contrasted with the saturated aqueous uranyl acetate solution and lead citrate solution. The cell ultrastructure was examined using an electron microscope PEM-125K at the accelerating voltage of $75 \mathrm{kV}$, which is equipped with the imaging and analysis system CAI-01A (JSC "SELMl", Ukraine) using a CCD camera DX 2 and a software package developed by KAPPA company (Germany) [3,13].

The results of qualitative research (case reports, case-series) were statistically processed using the software package STATISTICA 9.0. (StatSoft), license type: Freeware. When analyzing the frequency of qualitative traits (expressed as a percentage), the $p$ value of the Fisher test was used. The results of the studies are presented in the text as frequency \pm standard deviation $(\% \pm \sigma)$.

All patients were consulted by related specialists, including urologists, and women additionally by gynecologists.

The study was performed in accordance with the ethical principles of the Declaration of Helsinki with the permission of the Bioethics Commission of the State Institute for Dermatology and Venereology of the National Medical Academy of Ukraine. 


\section{Results}

Study of the clinical course of trichomonas infection in the observed patients revealed that $82.8 \%$ of men and $90.6 \%$ of women complained of their urogenital tracts. Presence of mucous secretions was noted in $52.8 \%$ of men and $81.9 \%$ of women. $35.2 \%$ of men and $32.9 \%$ of women had burning sensation. Itching in the genital area was present in $17.1 \%$ of men and $21.6 \%$ of women. $23.4 \%$ of men and $28.1 \%$ of women had dysuric syndrome.

Among the examined women, the existing chronic syndromes were as follows: vulvovaginitis was diagnosed in $67.9 \%$, endocervicitis - in $61.4 \%$, adnexitis - in $59.9 \%$, cystitis - in $31.8 \%$ of women, erosion of the cervix - in $13.6 \%$ of patients and infertility in $9.1 \%$ of cases. Men were diagnosed with chronic prostatitis in $82.8 \%$ of cases, chronic urethritis in $69.7 \%$, epididymitis - in $9.9 \%$, balanitis - in $4.9 \%$ and erectile dysfunction and infertility in $22.7 \%$.

Particular attention was given to the group of 150 patients in whom the real-time PCR method verified the Trichomonas tenax and Pentatrichomonas hominis infection. We noted the presence of complaints (89.7\%) and clinical manifestations in (91.4\%) patients, namely, women had mucous discharge $(88.1 \%)$, genital itching $(74.1 \%)$, vulvovaginitis $(88.1 \%)$ and endocervicitis $(49.1 \%)$, while men had frequent desire to urinate $(32.1 \%)$, manifestations of chronic urethritis and prostatitis $(59.7 \%)$.

As shown by our studies, in $65.1 \%$ of patients examined, trichomoniasis was defined as a mixed infection with other STI agents, and the most significant were the pathologic associations with Ureaplasma urealyticum (26.1\%), Chlamydia trachomatis (16.7\%), Mycoplasma hominis and Mycoplasma genitalium (13.9\%) and with highly oncogenic types of Human papillomavirus as well $(15.6 \%)$.

In our opinion, the data obtained are relevant, since they demonstrate the species composition of opportunistic pathogenic microflora (OPM), which has been identified as associates with Trichomonas vaginalis, Trichomonas tenax and Pentatrichomonas hominis. Comparing the species composition of OPM, some differences were found, namely the overwhelming number of isolated microorganisms in association with $T$. vaginalis were represented by different types of streptococci and staphylococci, and a smaller part - by representatives of other families. Sex differences were also observed. Thus, strains of opportunistic pathogenic microorganisms in high levels of colonization were isolated in women (37.1\%). The leading place among the isolated bacterial strains was occupied by streptococci, and the percentage of detected staphylococci was slightly lower. However, the specific gravity of some species was higher than of others. Among the streptococci found in this group, there were the representatives of three species. The leading positions of the streptococcal component were taken by S. mitis and S. mutans (27.2\% and $15.9 \%$, respectively), and staphylococcal components - S. haemolyticus $(17.7 \%)$. The percentage of $S$. warneri detection (12.1\%) was slightly lower. A fairly high percentage of detection was reported for $E$. coli (11.9\%). In some women (5.8\%),
Klebsiella spp. was found, a microorganism, which has quite pronounced pathogenic properties and is not inherent to vaginal biotope.

According to the results of bacteriological studies in men, the results of microbial composition of urogenital biocenosis differed from the results obtained in women. Among the men (41.9\%), S. haemolyticus (19.5\%) was the "leader: of the isolated microorganisms, followed by the representative of the genus streptococci $-S$. mitis $(12.4 \%)$. It was reported that the streptococcal component of biocenosis in males was represented by only one species and was lower in percentage than in females. Klebsiella spp. had a higher detection percentage in males as compared to the female group, as the figure reached almost $9.9 \%$. However, E. coli isolates were obtained in less number of men as compared to women $-7.3 \%$. Unlike women, men were found to have a representative of enterobacteria - Proteus mirabilis (4.7\%). Given the fact that this microorganism should not be in this biotope, even a low detected percentage of it raises questions about how this pathogen from the large intestine got to urethra.

Study of OMP in patients with Trichomonas tenax and Pentatrichomonas hominis infection showed that the following pathogens and / or their groups are most often included in the relevant pathological microbial associations: Candida spp., Eubacterium spp., Mobiluncus spp./ Corynebacterium spp., Gardnerella vaginalis/Prevotella bivia/ Porphyromonas spp. Moreover, significant advantage in detection rate of some OPM in men could be noted, namely: Enterobacteriaceae, Streptococcus spp., Staphylococcus spp., Gardnerella vaginalis/Prevotella bivia/Porphyromonas spp., Eubacterium spp., Sneathia spp./Leptotrihia spp./Fusobacterium spp., Mobiluncus spp./Corynebacterium spp., Peptostreptococcus spp. As shown by our data, $14.5 \%$ of patients showed one type (group) of microorganisms, in one third of cases these were women (38.9\%), three or more types (groups) - in $64.6 \%$, and 6 or more were detected in every sixth patient $(18.8 \%)$. Gender differences in the detection rate of these microorganisms may be indicative of their adaptation to the genitourinary system of men, despite certain differences in alkalinity of the habitat. The detection rate of Atopobium vaginae, on the contrary, was higher among women. In the study of a group of apparently healthy humans, there were no markers of sexual infection, and the representatives of opportunistic pathogenic microflora were isolated in the amount of $10^{2} \mathrm{CFU} / \mathrm{cm}^{3}$ and less, in the form of single colonies, in particular, in women mainly S. epidermidis (52.5\%). and in males - S. saprophyticus (66.3\%).

One of the factors that challenges the diagnostics of Trichomonas vaginalis is the presence of atypical forms of parasites, as they greatly vary in terms of their shape, size, presence of flagella and nuclei [3]. In the study with a transmissible electron microscope (TEM) T. vaginalis, which were isolated from 55 patients with chronic infectious diseases of the genitourinary organs with sluggish course, had both rounded (oval) and classic (piriform) shape, however, oval morphotype was more common (68 \%) than piriform. This fact can also be extrapolated to the morphotypes that are likely to occur in vivo, since cultivation in a medium makes it impossible to convert 


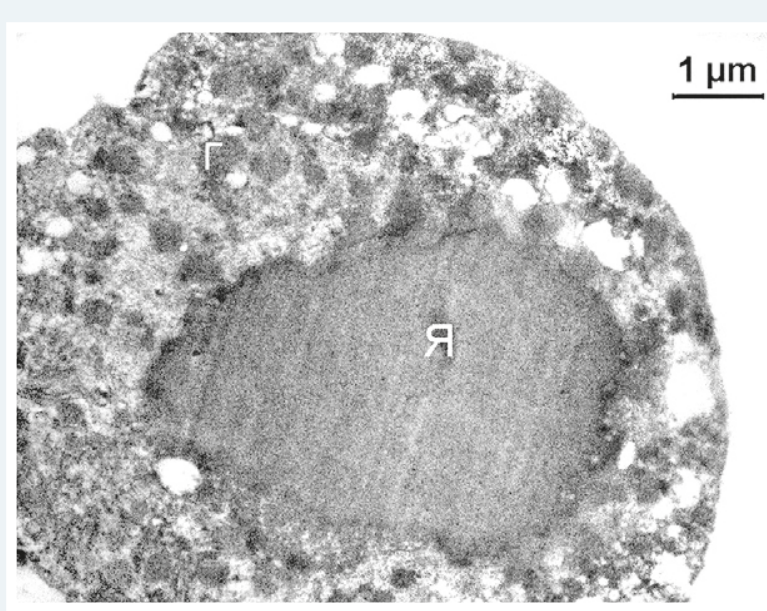

Fig. 1. Ultrastructure of $T$. vaginalis. Cytolemma is mostly preserved, contains no microvillus. The oval-shaped nucleus $(Я)$ is filled with chromatin of uniform structure and degree of compaction. The contour of the nuclear membrane is tortuous; nuclear pores are visible in the right.

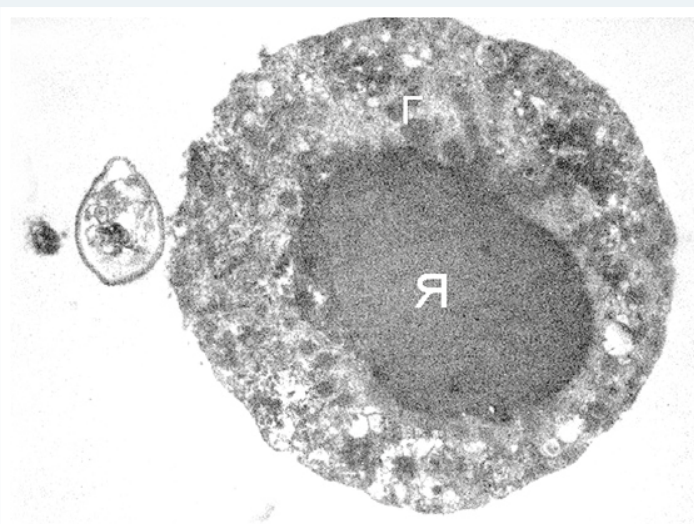

$2 \mu \mathrm{m}$

Fig. 3. Ultrastructure of $T$. vaginalis. $T$. vaginalis, which contacts $M$. genitalium, which is topped with a terminal slightly-elongated organelle $(\rightarrow)$. Integrity of the trichomonad cytolemma is impaired in some places. The nucleus (Я) is oval and filled with homogeneous chromatin of medium electron density. Small dense hydrogenosomes $(Г)$ and digestive vacuoles and vesicles of different size are identified in the cytoplasm.

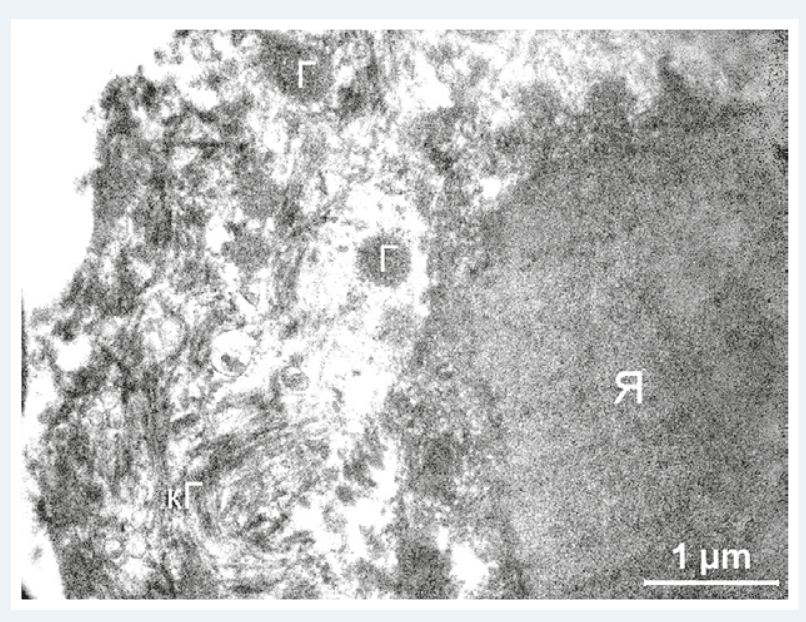

Fig. 2. Ultrastructure of $T$. vaginalis. There is a violation of integrity of the cell membrane. Membrane fragments and fibrous elements are immediately adjacent to the $T$. vaginalis nucleus. Hydrogenosomes $(\Gamma)$ have regular rounded shape and content of uniform electron density. There are circular cisterns of Golgi complex (КГ) and a small number of fringed vesicles in the cytoplasm.

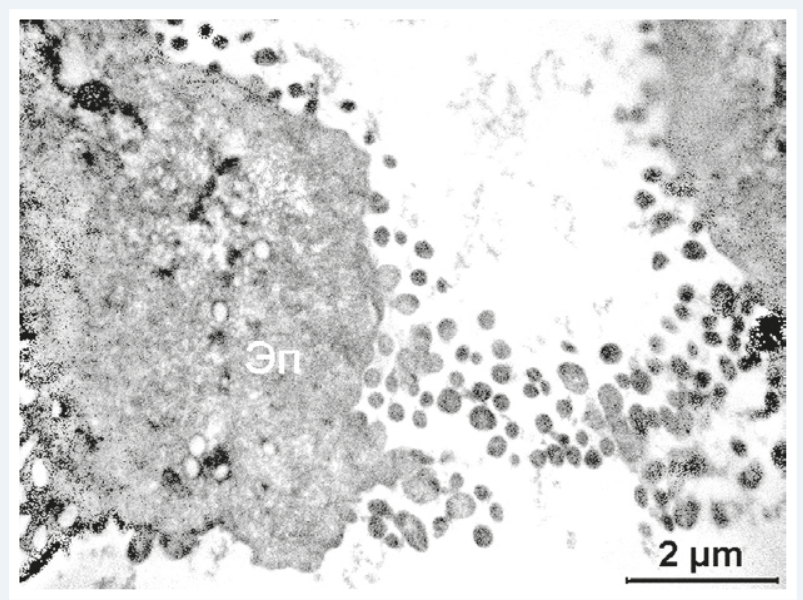

Fig. 4. Ultrastructure of $T$. vaginalis. Fragments of two deflated epitheliocytes, to the surface of which cocci adhere. Cytolemma of epitheliocytes forms a network of microvilli. Cytoplasm is mostly filled with fibrillar proteins of the cytoskeleton and small vacuoles.
$T$. vaginalis from one morphotype to another one. The round-shaped morphotypes are capable to divide via amitotic bud formation, rather than longitudinal division, like the typical piriform morphotypes. The following ultrastructural features were established for the oval morphotype: size variability (length 6-24 $\mu \mathrm{m}$ and width 5-12 $\mu \mathrm{m})$; undulating membrane and flagella in most cells were absent; which may be indicative of immobility of these trichomonads, axostyle, pelta and costa were also reduced; nucleus of rounded or oval shape is located mainly in the center of the cell; the nuclear envelope of the investigated cells retained integrity, the pore complexes were not common; the chromatin was presented with a homogeneous electron-dense material that uniformly filled the nucleus; the contour of the nuclear membrane was often tortuous; heterogeneous nucleoplasmic density was present; typical dictyosomes and the flattening of Golgi apparatus tanks were absent; accumulations of vesicles different in shape and density were observed around the nucleus; orderly arrangement of ribosomes (in piriform pathogens, they were located in the nucleus and organized into polysomes) was missing; internal membranes system was partially reduced, cell vacuolation was increased; polymorphism in size, shape and density of the hydrogenosomes were observed [3] (Fig. 1, 2).

Ultra-thin sections of specimens taken from the cervical canal, vagina and urethra revealed a large number of diverse microorganisms that were located between epithelial cells and adhered to epitheliocytes and, in particular, were in contact with T. vaginalis [3] (Fig. 3, 4).

Thus, chronic forms of trichomonas infection are most often microscopically represented with trichomonad-bacterial associations. Therefore, we used a complex therapy for treatment of urogenital trichomoniasis, which included application of modern antitrichomonad drugs in combination with antibiotics and pathogenetic therapy. Further confirmation of the concept of activity of nitroimidazole derivatives with systemic and local action 
against Trichomonas vaginalis as well as Trichomonas tenax and Pentatrichomonas hominis was obtained. This comprehensive approach provided the maximum eradication (94.9\%) of both trichomonads and concomitant opportunistic and pathogenic microflora, which minimized development of complications and recurrences.

\section{Discussion}

The data presented above show that the contemporary trichomonas infection continues to occupy a leading position in terms of prevalence and poses a threat to the health of both young and mature people; also it leads to complications that stipulate impairment of reproductive, sexual and urinary functions. We established that no significant gender differences were detected in detection rate of trichomonas infection agents in the genitourinary system of patients. Attention was drawn by the mean age of the examined patients, i.e. in spite of quite extensive age range (from 17 to 80 years), they were predominantly the patients above thirty. This fact emphasizes the problem of the so-called "trichomonas carrier state" when patients with oligosymptomatic course of infection have no idea about presence of trichomonas in them. The reported rate shows high uniformity of this contingent and witnesses to the need for timely examination and full-scale treatment, especially of the patients of fertile age, taking into account the fact that this is exactly the time when they plan pregnancy and have children, and the index of infertility reaches almost $12 \%$ according to our data. Upon analysis of the obtained data, it was shown that, among the male patients, a higher percentage of positive tests for Trichomonas vaginalis (82.8\%) was reported in the patients with chronic prostatitis, as compared with the patients with chronic urethritis $(69.7 \%)$. Women had a rather high detection rate of vulvovaginitis $(67.9 \%)$ and approximately equal percentages of chronic endocervicitis and adnexitis (61.4\% and 59.9\%), respectively. In our opinion, it is an interesting fact that there is a high rate of chronic cystitis (55.9\%) in women aged 45 years and more.

Nevertheless, we have concerns about the fact that contemporary trichomonas monoinfection occurs much less frequently, and in most cases manifests in a form of pathological microbial associations (up to $70 \%$ ), which adds specific peculiarities to the disease course, and as a consequence - complicates the choice antibacterial agents for etiotropic therapy. Our research is another confirmation of this trend. It was further confirmed that in patients with urogenital trichomoniasis, two morphotypes of virulent forms of $T$. vaginalis are distinguished: piriform and oval, with the latter morphotype outnumbers greatly, namely, the round-shaped forms made up the majority (67\%). The results of the ultrastructure study suggest that the round-shaped forms of $T$. vaginalis are one of the virulent forms rather than degenerative, as it was considered previously, since they have the required morphological organization and, therefore, are capable of causing a pathogenic effect on the macroorganism. However, the structural changes observed in cytoplasm of round-shaped $T$. vaginalis cells indicate a decrease in their physiological activity, which may witness to adverse conditions experienced by them in the human body (e.g. the effect of anti-protist drugs), which coincides with the other thoughts $[1,4,6,10,13]$. However, the issue of possible affiliation of various trichomonad morphotypes to various $T$. vaginalis serotypes or even to other Trichomonas species remains open and requires further study.

Analysis of our studies revealed the widespread prevalence of protozoal invasions in genitourinary system caused by Trichomonas tenax and Pentatrichomonas hominis. Presence of chronic inflammatory process in the genitourinary system of each patient enables us to make assumptions about the prospect of current consideration of Trichomonas tenax and Pentatrichomonas hominis as the etiological factor for emergence and/or course of urogenital infections, in particular, in pathological microbial associations, which stipulates - in our opinion the need for their mandatory eradication.

High rate of Trichomonas vaginalis invasion (48.3\%) established by optical microscopy and media inoculation of Trichomonas tenax (18.2\%) and Pentatrichomonas hominis $(67.1 \%$ ) during real-time PCR indicates the need for timely and informative diagnostics of these microorganisms in order to prevent any possible complications. The detection rate of Trichomonas vaginalis was higher particularly as a result of inoculation on liquid nutrient media. Presence of agents in Gram stained smears was verified almost twofold less, and PCR diagnostics was the least sensitive (4\%) in this case. On the contrary, verification of Trichomonas tenax and Pentatrichomonas hominis in the urinary tract using the real-time PCR method was maximally informative. Therefore, it was suggested that during trichomonad verifications by inoculation on the appropriate nutrient medium often take Trichomonas non vaginalis is often confused with Trichomonas vaginalis, namely Trichomonas tenax or Pentatrichomonas hominis [15-17].

The scientific novelty of the data obtained is confirmed by the fact that protozoan invasions in addition to Trichomonas vaginalis are also capable of causing by Trichomonas tenax and Pentatrichomonas hominis. New data on the ultrastructural features of the oval morphotype of $T$. vaginalis make it possible to attribute it to virulent forms of the pathogen, since they have the appropriate morphological organization and are capable of inflicting pathogenic influence.

A clinical feature of modern trichomoniasis is that it runs chronically in the form of associations with other STIS (Ureaplasma urealyticum, Chlamydia trachomatis, Mycoplasma hominis and Mycoplasma genitalium, Human Papillomavirus). The incidence of trichomoniasis depends on the localization of infectious processes (vulvovaginitis, endocervicitis, adnexitis in women, and prostatitis in men).

The practical relevance of the data presented is that determining the type of protozoa, as well as their morphological forms, plays a crucial role in preventing STI complications, recurrences and re-infections through the selection of adequate treatment and diagnostic and preventive measures $[1,5,14,18]$.

\section{Conclusions}

1. Trichomonas vaginalis invasion of the genitourinary organs continues to be a leader in prevalence among 
STIs. The diagnosis of trichomoniasis established by optical microscopy and medium inoculation was verified in $48.3 \%$ of patients. Moreover, the peak incidence was reported among the patients of the most reproductive age, which proves the importance of the invasion monitoring, taking into account the age of patients.

2. It is confirmed that presence of Trichomonas vaginalis leads to complications that cause impaired reproductive, sexual and urinary functions of the body. In particular, it has been shown that the detection rate of this microorganism depends on localization and the course of infectious processes, namely in women with chronic vulvovaginitis $(67.9 \%)$, endocervicitis $(61.4 \%)$ and adnexitis (59.9\%) and in men with a sluggish course of chronic prostatitis $(48.1 \%)$.

3. According to real-time PCR data, protozoal invasions of the urogenital system, beside Trichomonas vaginalis, may be also caused by Trichomonas tenax (18.2\%) and Pentatrichomonas hominis (67.1\%), which should be considered as important pathological factors of urinary dysbiosis in the urogenital system in both women and men with chronic inflammatory processes, which, in our opinion, necessitates their mandatory eradication.

4. Contemporary trichomoniasis in most cases (up to $70 \%$ ) manifests as pathological microbial associations, in particular with other STIs, namely the most significant were the pathological associations with Ureaplasma urealyticum (26.1\%), Chlamydia trachomatis (16.7\%), Mycoplasma hominis and Mycoplasma genitalium (13.9\%), OPM (up to $65 \%$ ), as well as with highly oncogenic types of $\mathrm{Hu}$ man Papillomavirus (15.6\%), which affects the disease course and its complications, as well as the choice of effective therapeutic, diagnostic and preventive measures.

5. The obtained data on the ultrastructural features of $T$. vaginalis of atypical oval morphotype in patients with chronic trichomoniasis allows to attribute it to the virulent form of the agent, rather than to the degenerative one, since it has the necessary morphological organization and is able to cause pathogenic effect on the macroorganism, and currently it is identified more often (68\%) than the typical piriform morphotype.

Prospect of further research is related to the analysis of correlation between the clinical, etiological and morphological characteristics of contemporary trichomoniasis at the expense of both Trichomonas vaginalis and Trichomonas non vaginalis, with the consideration of the co-infections, in particular, study of the issue of possible affiliation of various trichomonad morphotypes to various $T$. vaginalis serotypes or even to other Trichomonas species, which can improve the clinical, diagnostic, organizational ad preventive measures against the trichomonad invasion in human urogenital tract.

\section{Funding}

Topic of the scientific research SI "Institute of Dermatology and Venereology of National Academy of Medical Sciences of Ukraine" "Optimization of laboratory system for diagnostics of syphilis and trichomoniasis for various levels of medical assistance to the population in the face of social instability and emergencies", within the framework of budget financing (№ 0116U003595).
Conflicts of interest: authors have no conflict of interest to declare. Конфмікт інтересів: віАсутній.

Надійшла Ао редакції / Received: 18.12.2019

Після Аоопрацювання / Revised: 12.01.2019

Прийнято Ао Аруку / Accepted: 14.01.2019

\section{Information about the authors:}

Mavrov H. I., MD, PhD, DSc, Professor, Head of the Department of Studying the Influence of HIV Epidemic on the Problem of Sexually Transmitted Infections, SI "Institute of Dermatology and Venereology of National Academy of Medical

Sciences of Ukraine", Kharkiv, Head of the Department of Dermatovenereology and HIV/AIDS, Kharkiv Medical Academy of Postgraduate Education, Ukraine.

ORCID ID: 0000-0002-3645-2792

Osinska T. V., MD, PhD, Senior Researcher of the Department of Studying the Influence of HIV Epidemic on the Problem of Sexually Transmitted Infections, SE "Institute for Dermatology and Venereology of the National Academy of Medical Sciences of Ukraine", Kharkiv.

ORCID ID: 0000-0002-2683-4957

Fedorych P. V., MD, PhD, Associate Professor, Head of the Course of Dermatology and Venereology, Professor of the Department of Military General Practice and Family Medicine, Ukrainian Military Medical Academy of the Ministry of Defense of Ukraine, Kyiv. ORCID ID: 0000-0001-8273-0821

\section{Відомості про авторів:}

Мавров Г. І., А-р меА. наук, професор, зав. відАілу вивчення впливу епідемії ВІ^ на проблему інфекцій, що переАаються статевим шляхом, АУ «нститут Аерматології та венерології НАМН України", м. Харків, зав. каф. дерматовенерології та ВI//CHIAу, Харківська медична акаАемія післядипломної освіти, Україна. Осінська Т. В., канА. меА. наук, старший науковий співробітник віАдіяу вивчення впливу епідемії ВІ^ на проблему інфекцій, що передаються статевим шляхом, АУ «Інститут Аерматології та венерології НАМН України", м. Харків.

Федорич П. В., канА. меА. наук, Аоцент, начальник курсу Аерматології та венерології, професор каф. військової загальної практики - сімейної медицини, Українська військово-медична академія МО України, м. Київ.

\section{Сведения об авторах:}

Мавров Г. И., А-р меА. наук, профессор, зав. отАела изучения влияния эпидемии ВИЧ на проблему инфекций, переАающихся половым путем, ГУ “Институт Аерматологии и венерологии НАМН Украины", г. Харьков, зав. каф. Аерматовенерологии и ВИЧ/СПИАа, Харьковская меАицинская академия последипломного образования, Украина.

Осинская Т. В., канА. меА. наук, старший научный сотрудник отАела изучения влияния эпиАемии ВИЧ на проблему инфекций, передающихся половым путем, ГУ “Институт Аерматологии и венерологии НАМН Украины", г. Харьков. Федорич П. В., канА. меА. наук, Аоцент, начальник курса Аерматологии и венерологии, профессор каф. военной общей практики - семейной медицины, Украинская военномеАицинская акаАемия МО Украины, г. Киев.

\section{References}

[1] Hinderfeld, A. S., \& Simoes-Barbosa, A. (2020). Vaginal dysbiotic bacteria act as pathobionts of the protozoal pathogen Trichomonas vaginalis. Microbial Pathogenesis, 138, Article 103820. https://doi.org/10.1016/j. micpath.2019.103820

[2] Kissinger, P. (2015). Trichomonas vaginalis: a review of epidemiologic, clinical and treatment issues. Bmc Infectious Diseases, 15, Article 307. https://doi.org/10.1186/s12879-015-1055-0

[3] Fedorych, P. V., Mavrov, G. I., Dzhoraeva, S. K., \& Osinska, T. V. (2018). Ul'trastrukturnye osobennosti morfotipov Trichomonas vaginalis, vydelennykh ot bol'nykh s khronicheskoi trikhomonadnoi invaziei [Ultrastructural features of the Trichomonas vaginalis morphotypes isolated from patients with chronic Trichomonas invasion]. Dermatolohiia ta venerolohiia, (4), 17-22. [in Russian]. 
[4] Kemmerling, U., Osuna, A., Schijman, A. G., \& Truyens, C. (2019). Congenital Transmission of Trypanosoma cruzi: A Review About the Interactions Between the Parasite, the Placenta, the Maternal and the Fetal/Neonatal Immune Responses. Frontiers in Microbiology, 10, Article 1854. https://doi.org/10.3389/fmicb.2019.01854

[5] Bondarenko, G. M., Mavrov, G. I., Osinskaia, T. V., Unuchko, S. V., Gubenko, T. V., Shcherbakova, Yu. V., \& Sobol, N. V. (2016). Perynatalna invaziia Trichomonas vaginalis yak problema reproduktyvnoi medytsyny [Trichomonas vaginalis prenatal invasion as a problem of reproductive medicine]. Zhurnal Natsionalnoi akademii medychnykh nauk Ukrainy, 22(3-4), 368-376. [in Ukrainian].

[6] Edwards, T., Burke, P., Smalley, H., \& Hobbs, G. (2016). Trichomonas vaginalis: Clinical relevance, pathogenicity and diagnosis. Critical Reviews in Microbiology, 42(3), 406-417. https://doi.org/10.3109/10 $40841 \times .2014 .958050$

[7] Van Der Pol, B. (2016, Jan). Clinical and Laboratory Testing for Trichomonas vaginalis Infection. Journal of Clinical Microbiology, 54(1), 7-12. https://doi.org/10.1128/jcm.02025-15

[8] Gaydos, C. A., Schwebke, J., Dombrowski, J., Marrazzo, J., Coleman, J., Silver, B., Barnes, M., Crane, L., \& Fine, P. (2017). Clinical performance of the Solana (R) Point-of-Care Trichomonas Assay from clinician-collected vaginal swabs and urine specimens from symptomatic and asymptomatic women. Expert Review of Molecular Diagnostics, 17(3), 303-306. https://doi.org/10.1080/14737159.2017.1282823

[9] Mielczarek, E., \& Blaszkowska, J. (2016). Trichomonas vaginalis: pathogenicity and potential role in human reproductive failure. Infection, 44(4), 447-458. https://doi.org/10.1007/s15010-015-0860-0

[10] Howe, K., \& Kissinger, P. J. (2017). Single-Dose Compared With Multidose Metronidazole for the Treatment of Trichomoniasis in Women: AMeta-Analysis. Sexually Transmitted Diseases, 44(1), 30-35. https:// doi.org/10.1097/olq.0000000000000537

[11] Shcherbakova, Yu., Kutasevych, Ya., Mavrov, G., Osinskaya, T., Kalashnikova, I. (2019, September 5-7). Assessment of psycho-emotional state in patients with sexually transmitted infections in vulnerable groups to HIV infection. 33rd IUSTI - Europe Congress on Sexually Transmitted Infections, (pp. 109-110). Tallinn.

[12] Najafi, A., Nosrati, M. R. C., Ghasemi, E., Navi, Z., Yousefi, A., Majidiani, H., Ghaneialvar, H., Sayehmiri, K., Galvan-Ramirez, M. D., \& Fakhar, M. (2019). Is there association between Trichomonas vaginalis infection and prostate cancer risk?: A systematic review and meta-analysis. Microbial Pathogenesis, 137, Article 103752. https:// doi.org/10.1016/j.micpath.2019.103752

[13] Raja, I. M., Basavareddy, A., Mukherjee, D., \& Meher, B. R. (2016). Randomized, double-blind, comparative study of oral metronidazole and tinidazole in treatment of bacterial vaginosis. Indian Journal of Pharmacology, 48(6), 654-658. https://doi.org/10.4103/0253-7613.194843

[14] Fedorich, P. V., \& Mavrov, G. I. (2018). Doslidzhennia skladu mikrobnykh asotsiatsii zbudnykiv protozoinykh invazii z mikrofloroiu, shcho asotsiiovana $z$ bakterialnym vahinozom u khvorykh na khronichni infektsii sechostatevoi systemy [Combination of protozoan invasion agents with bacterial vaginosis associated microflora in patients with genital chronic inflammatory diseases]. Dermatovenerologiya. Kosmetologiya. Seksopatologiya, (1-4), 6-13. [in Ukrainian]

[15] Fedorych, P. V., Zeleny, S. B., Sadovska, O. A., \& Dudikova, K. V. (2017). Porivniannia efektyvnosti diahnostyky trykhomoniazu za kulturalnym metodom ta metodom polimeraznoi lantsiuhovoi reaktsii z vykorystanniam praimeriv dlia vyiavlennia Trichomonas vaginalis, Trichomonas tenax ta Pentatrichomonas hominis [Comparison of effectiveness of trichomoniasis diagnosis by cultural method and polymerase chain reaction method with the use of primers for the detection of Trichomonas vaginalis, Trichomonas tenax and Pentatrichomonas hominis]. Ukrainskyi zhurnal dermatolohii, venerolohii, kosmetolohii, (1), 65-69. [in Ukrainian].

[16] Ananieva, M. M. (2018). Etiological and pathogenetic aspects of non-specific bacterial vaginosis. Zaporozhye Medical Journal, 20(3), 432-436. https://doi.org/10.14739/2310-1210.2018.3.132124

[17] Fedorych, P. V. (2018). Vyiavlennia Pentatrichomonas hominis pry kolpotservitsyti ta salpinhooforyti [Detection of Pentatrichomonas hominis of colpocervicite and salpingooforitis]. Dermatolohiia ta venerolohiia, (3), 77-79. [in Ukrainian]. 